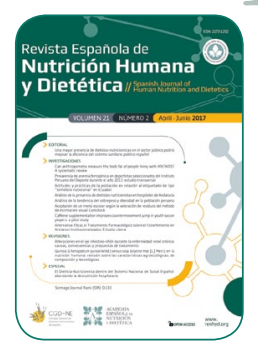

RESEARCH ARTICLE

\title{
Caffeine supplementation improves countermovement jump in youth soccer players: a pilot study
}

\author{
Juan Diego Hernández-Camacho ${ }^{a, b, *}$, Javier Vázquez-Carrión ${ }^{b}$, Elena Fuentes-Lorca , \\ Heliodoro Moya-Amaya
}

a

iversidad Pablo de Olavide, Sevilla, España.

b Unidad de Optimización del Rendimiento, Prevención y Recuperación de Lesiones, AD Nervión, Sevilla, España.

*jdhercam@alu.upo.es

Received: 09/12/2016; accepted: 20/02/2017; published: 16/06/2017.

\section{KEYWORDS}

Caffeine;

Dietary Supplements;

Athletic Performance;

Soccer;

Double-Blind Method.
Caffeine supplementation improves countermovement jump in youth soccer players: a pilot study

\section{ABSTRACT}

Introduction: The objective of this study was to analyze the effect of caffeine ingestion in soccer performance, particularly in the countermovement jump test (CMJ).

Material and Methods: A total of 17 players from a U-19 amateur Spanish team participated in this pilot study. A double-blind placebo-controlled randomized experimental design was used in 2 different sessions (1.5 hour per session) separated by 1 week. CM] was collected at the beginning and at the end of sessions; Rating of Perceived Exertion (RPE) was recorded. Players ingested caffeine or placebo at the beginning of session (minute 0 of session), providing a total of $4 \mathrm{mg}$ of caffeine or a placebo per $\mathrm{kg}$ of body mass. Side effects from caffeine and placebo ingestions were analyzed. The effect sizes (ES) were calculated using values for Cohen's and Quantitative differences were assessed qualitatively (QA).

Results: The jump height with caffeine supplementation at the beginning of training was 37.03 $( \pm 3.87) \mathrm{cm}$ and at the end was $39.35( \pm 4.05) \mathrm{cm}$, obtaining significant improvements $(p<0.05$; ES:0.56; QA:99/1/0). Significant differences on CM] at the end of the training session between caffeine and placebo groups were observed $(39.35[ \pm 4.05] \mathrm{cm}$ vs. $36.85[ \pm 3.15] \mathrm{cm} ; \mathrm{p}<0.05$; ES:0.65; QA:0/1/99). Significant differences on RPE between groups were observed. A nonsignificant tendency to suffer more side effects with caffeine ingestion was obtained.

Conclusions: This study shows how the ingestion of $4 \mathrm{mg}$ of caffeine per $\mathrm{kg}$ of body mass could be an ergogenic aid to improve soccer performance. However, further studies with bigger soccer players sample would be necessary to refute the present results. 
La suplementación con cafeína mejora el salto en contramovimiento en jugadores jóvenes de fútbol:
estudio piloto

\section{PALABRAS CLAVE}

Cafeína;

Suplementos

Dietéticos;

Rendimiento

Atlético;

Fútbol;

Método Doble Ciego.

\section{RESUMEN}

Introducción: El objetivo del presente estudio fue analizar el efecto de la ingestión de cafeína en el rendimiento en fútbol, específicamente en el test de salto en contramovimiento (CMJ).

Material y Métodos: 17 jugadores de la categoría Sub-19 de un equipo amateur español participaron en el estudio piloto. Se siguió un diseño a doble ciego, placebo-control, aleatorizado en 2 entrenamientos (1,5 horas/sesión) separados por 1 semana. El CMJ se recogió al inicio y, al final de las sesiones, la tasa de esfuerzo percibido (RPE) fue recogida. Los jugadores tomaron cafeína o placebo al inicio del entrenamiento (minuto 0), proveyendo $4 \mathrm{mg} / \mathrm{kg}$ de masa corporal de cafeína o placebo. Se analizaron los efectos secundarios provenientes de la cafeína y del placebo. Los tamaños de efecto (ES) se calcularon utilizando valores para Cohen y las diferencias cuantitativas se evaluaron cualitativamente (QA).

Resultados: La altura del salto media cuando se ingirió cafeína fue $37,03( \pm 3,87) \mathrm{cm}$ al inicio y $39,35( \pm 4,05) \mathrm{cm}$ al final del entrenamiento, obteniendo una mejora significativa $(p<0,05$; ES:0,56; QA:99/1/0). Se observaron diferencias significativas en el CMJ al final de los entrenamientos entre la ingestión con cafeína y placebo $(39,35[ \pm 4,05] \mathrm{cm}$ vs. $36,85[ \pm 3,15] \mathrm{cm} ; \mathrm{p}<0,05$; ES:0,65; QA:0/1/99). Se obtuvieron diferencias significativas en la RPE entre los grupos. Se observó una tendencia no significativa a sufrir más efectos secundarios cuando se ingirió cafeína.

Conclusiones: Este estudio muestra como la ingestión de $4 \mathrm{mg} / \mathrm{kg}$ de cafeína podría ser una ayuda ergogénica para mejorar el rendimiento en fútbol. Se requieren más estudios con mayor tamaño muestral para confirmar los resultados.

\section{CITA}

Hernández-Camacho JD, Vázquez-Carrión J, Fuentes-Lorca E, Moya-Amaya H. Caffeine supplementation improves countermovement jump in youth soccer players: a pilot study. Rev Esp Nutr Hum Diet. 2017; 21(2): 155-63. doi: 10.14306/renhyd.21.2.331

\section{INTRODUCTION}

Caffeine (1,3,7-trimethylxanthine, molecular weight $194.2 \mathrm{~g} / \mathrm{mol}$ ) is one of the most consumed supplements in individual sports since 2004, when the World Anti-Doping Agency's (WADA) removed it from the banned substance list. But it has been intensely studied in team sport in recent years.

The mechanism of physiological action is explained by the competitive inhibition of adenosine receptors, especially A1 and $\mathrm{A} 2 \mathrm{~A}$ receptors. Additionally, it has been showed that caffeine ingestion will increase catecholamines plasma concentration $^{1}$; consequently these effects could improve sport performance.

Caffeine administration has been used in a wide variety of team sports in order to improve sport performance. The effectiveness of caffeine on physical rugby performance has been previously analyzed. Providing $3 \mathrm{mg} / \mathrm{kg}$ body mass (BM) of caffeine or placebo, sixteen woman from a rugby sevens team performed a 15-s maximal jump test, a $6 \times 30 \mathrm{~m}$ sprint test and played three rugby games ${ }^{2}$. Caffeine obtained an increase in muscle power output during the jump series, in running pace during the rugby games and pace at sprint speed $^{2}$. Another research determined the effect derived from caffeine in physical performance in volleyball players. Fifteen male volleyball players performed volleyball-specific tests and volleyball match was played and recorded, after the ingestion of caffeine $(3 \mathrm{mg} / \mathrm{kg} \mathrm{BM})$ or placebo ${ }^{3}$. A higher ball velocity, a higher mean jump height in squat jump (SJ), in countermovement jump (CMJ) and in 15-s rebound jump test $(15 R])$ were recorded when players ingested caffeine. They also performed more successful volleyball actions with caffeine than with placebo in the volleyball match ${ }^{3}$. In addition to these studies in team sports, caffeine has been 
Caffeine supplementation improves countermovement jump in youth soccer players: a pilot study

widely studied in soccer. Del Coso and Cols. investigated the effects of caffeine on performance where nineteen soccer players performed a 15 -s maximal jump test, $7 \times 30 \mathrm{~m}$ repeated sprint test and played a simulated game when previously they have ingested caffeine $(3 \mathrm{mg} / \mathrm{kg}$ BM) as energy drink or a decaffeinated drink $k^{4}$. Caffeine reported a higher mean jump height, a higher mean running speed during sprint series and higher distance covered at a speed higher than $13 \mathrm{~km} / \mathrm{h}$. Even, other study examined caffeine in physical soccer performance in female players. Eighteen women players ingested energy drink providing caffeine (3mg/kg BM) or a placebo ${ }^{5}$. Improvements in CMJ height and in the average peak running in sprint test were observed with caffeine. Furthermore, they run more distance in a simulated soccer match and more distance covered at $>18 \mathrm{~km} / \mathrm{h}$ with caffeine ${ }^{5}$. Therefore, it seems that caffeine could enhance physical performance in team sports.

However, other studies have analyzed effects of caffeine in team sports, finding that this strategy has not shown improvements. Tucker and Cols. ${ }^{6}$ has not found effects from caffeine ingestion in elite-level male basketball players when they completed a maximal-effort test on a treadmill and a vertical jump test, they had ingested caffeine ( $3 \mathrm{mg} / \mathrm{kg}$ BM) or placebo. Another research determined effect derived from caffeine on match activities and development of fatigue during a soccer match; players ingested caffeine $(6 \mathrm{mg} / \mathrm{kg} \mathrm{BM})^{7}$. No increases in total distance covered, high intensity running, sprinting distance and acceleration counts were obtained with caffeine compared with placebo. It was concluded that oral caffeine ingestion did not appear to present an ergogenic effect in young soccer players ${ }^{7}$.

A recent article ${ }^{8}$ studied effects of caffeine supplementation alone or with carbohydrate on soccer tests performance after a previous training. Players ingested $1.2 \mathrm{~g} / \mathrm{kg}$ of body mass each hour of carbohydrate, $6 \mathrm{mg} / \mathrm{kg}$ of BM of caffeine, carbohydrate combined with caffeine or placebo after a previous training. Obtaining no effects in tests performance, caffeine was not able to improve performance. A specific energy drink has been examined on repeated sprint performance in woman athletes ${ }^{9}$. They performed the modified T test after the ingestion of $255 \mathrm{~mL}$ of placebo or caffeinated energy drink providing $1.3 \mathrm{mg} / \mathrm{kg}$ caffeine. No difference was observed in sprint performance or in heart rate. Thus, it is certainly true that some studies did not find benefits in sport performance with caffeine administration.

Soccer is a team sport characterized by intermittent highintensity actions interspersed with period of low-intensity. Particularly, factors such as total distance, high intensity running and very high intensity running could play an important role in soccer performance ${ }^{10}$.
The purpose of the present research was to determine the effect of caffeine ingestion in sport performance, especially in $\mathrm{CM}$ ] test in soccer players. Rating of perceived exertion and side effects derived of caffeine ingestion were recorded.

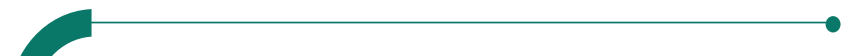 \\ MATERIAL AND METHODS}

Subjects: A total of seventeen male soccer players from a U-19 amateur Spanish team voluntary participated in this research. All of them essayed CMJ in previous sessions to familiarize with experimental procedures and participants had not history of dangerous secondary effects from caffeine consume. They delivered informed written consents which had been signed by their parents. Players performed three training seasons per week, data were collected in the first training season of two consecutive weeks. They had trained for $\sim 1.5$ hour/day, 4 day/week (including a weekly competitive match) during the previous year. All players were regularly involved in competitive matches and trainings.

Caffeine Dose: There are studies which uses different dose in order to get ergogenic effects from caffeine supplementation ${ }^{2-6,11-16}$. A dose between $3-6 \mathrm{mg}$ of caffeine per kilogram of BM seems to have benefits without negative side effects and therefore a medium dose of $4 \mathrm{mg} / \mathrm{kg}$ of BM was used. Caffeine and placebo supplements were administrated in pills. Placebo composition was microcrystalline cellulose. Caffeine or placebo was ingested 90 minutes before the CM] final test. In Figure $1 \mathrm{~A}$ can be observed the design of both sessions.

Countermovent Jump (CMJ): $\mathrm{CMJ}$ has been used in numerous studies to evaluate the ergogenic effect of caffeine ingestion in team sports performance $3,5,14,17$. Players performed CMJs at the beginning and at the end of training sessions. Before countermovement jump test, players performed a soccerspecific standardized warm-up in both sessions. Participants performed 5 maximal countermovement jumps with a minute of rest between repetitions ${ }^{3}$. The best and the worse jump were eliminated and the result was the average of the rest of jumps. Chronojump-Boscosystem used in the present research has been validated to measure vertical jumps ${ }^{18}$.

Rating of Perceived Exertion (RPE): RPE ${ }^{19}$ was recorded on a scale of 6-20 following the completion of each training session. The question was "How hard has been the session today?". Previously, RPE has been used to analyze the ergogenic effect of caffeine supplementation in team sports $^{20}$. 
Initial Tiredness Scale: A scale of 1-10 was used at the beginning of the session in order to know the initial tiredness of the players, asking to the question "How tired are you today?" the answers were from 1-Nothing to 10-Very much. This instrument was an ad hoc scale. These data were recorded before the warn-up at the beginning of the session.

Side effects: To analyze side-effects resulting from caffeine ingestion in the following night hours a non-parametric test for dichotomic variables was recorded, this questionnaire has been previously used to analyze side-effects from caffeine in sport $2,15,21,22$. The next morning of each training sleep quality, nervousness, gastrointestinal problems and other discomforts related to caffeine ingestion were evaluated in soccer players with a questionnaire including 8 items on a yes/no scale.

Experimental Design: Players performed two experimental training sessions separated by 1 week where they ingested $4 \mathrm{mg}$ caffeine per $\mathrm{kg}$ of $\mathrm{BM}$ or a placebo. CMJ tests were recorded at the beginning and at the end of the 90 minutes of training, this training included 45 minutes of soccer match and 45 minutes of physical exercises at a medium-high intensity. Players were encouraged to carry out the training session a high intensity level. Goalkeepers executed the same training session protocol to the rest of players. Players ingested caffeine or placebo after the initial measures, it was a double-blind, placebo-controlled, randomized experimental design. The soccer coach administered the pills to the players. The present research constituted a pilot study due to a reduce athletes sample. Moreover, the selection of soccer players was not probabilistic. They abstained from caffeine ingestion in their diet for 24 hour before each experimental trial. Players were provided with a list of foods and drinks containing caffeine and asked to avoid these as previous studies ${ }^{1,5}$. The experimental protocol was written following the ethics rules from Helsinki Declaration. All experimental procedures were in accordance with the Pablo de Olavide University Ethical Committee rules. In Figure 1B can be observed the experimental design.

Statistical Analyses: SPSS 20 software was used for statistical analyses. Descriptive statics mean ( \pm standard deviation) were reported. The Shapiro-Wilk test was conducted to analyze the normality distribution and a paired sample $T$ test or a Wilconxon test was performed to compare differences between pre-caffeine ingestion and post-caffeine ingestion and between groups. The effect sizes (ES) were conducted according to previous procedures 23,24 using values for Cohen's ( $<0.2$ small effect; $<0.5$ medium effect; <0.8 large effect). Quantitative differences were assessed qualitative $(\mathrm{QA})$ as a previous reference ${ }^{25}<1 \%$ almost certainly not; $1-5 \%$ very unlikely; $5-25 \%$ unlikely; 25-75\% possible; $75-95 \%$ probably; $95-99 \%$ very likely and $>99 \%$ almost certain. Statistical significance was accepted at a level of $p \leq 0.05$. Cronbach alpha coefficient was calculated in order to meet the reliability of side effects questionnaire.

Figure 1. Experimental protocol.

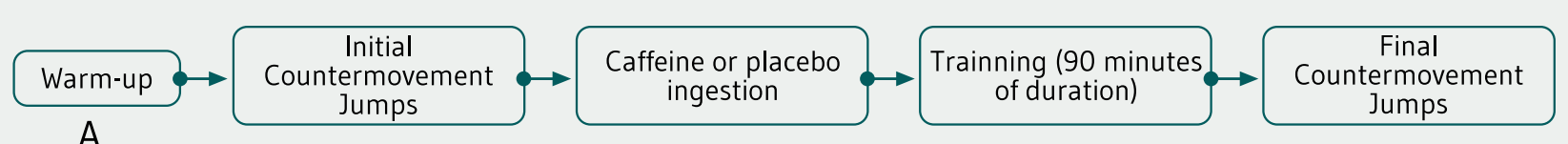

A

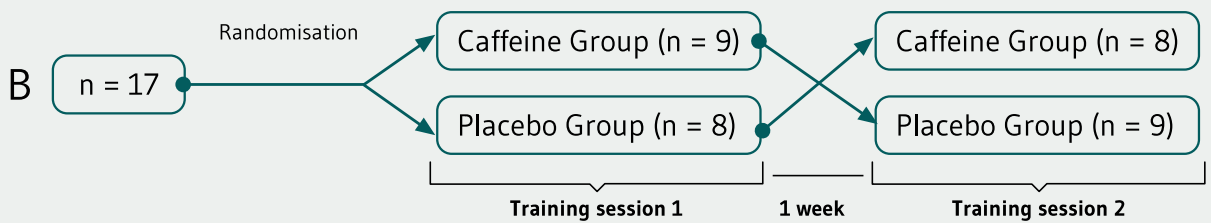

A: Design of both sessions. Caffeine or placebo was ingested after the standardized warm-up and initial CM] tests.

B: Experimental design. Football players were divided in caffeine and placebo groups: The two training sessions analyzed were separated by 1 week. 


\section{RESULTS}

The mean age between soccer players was $17.65( \pm 0.48)$ years old and the mean weight was $69.08( \pm 7.59) \mathrm{kg}$. The distribution in different position in the field was goalkeepers $(n=2)$, fullbacks $(n=3)$, defenders $(n=3)$, midfielders $(n=6)$ and strikers $(n=3)$. Table 1 show the soccer players distributed in the two groups studied.

Jump Performance: Jump height was significantly improved between soccer players that ingested caffeine supplement (37.03 [ \pm 3.87$] \mathrm{cm}$ vs. $39.35[ \pm 4.05] \mathrm{cm} ; \mathrm{p}<0.05 ; \mathrm{ES}: 0.56$;
QA:99/1/0). Mean jump heights in caffeine administration are shown in Figure 2A where it is possible to observe individually the effect of caffeine ingestion on jump height.

There was not significant differences on jump height between players from caffeine and placebo groups at the beginning of the training session $(37.03[ \pm 3.87] \mathrm{cm}$ vs. $36.02[ \pm 3.10]$ $\mathrm{cm} ; \mathrm{p}=0.242 ; \mathrm{ES}:-0.26$; $Q A: 2 / 37 / 61)$. Neither significant improvement were observed on jump height at the beginning and at the end on the training in placebo group (36.02 $[ \pm 3.10] \mathrm{cm}$ vs. $36.85[ \pm 3.15] \mathrm{cm} ; \mathrm{p}=0.165 ; \mathrm{ES}: 0.25$; QA:68/31/1). This can be observed in Figure $2 B$, this picture describe the effect one by one of placebo administration in jump performance.

Table 1. Distribution of athletes in the two groups examined.

\begin{tabular}{|c|c|c|c|c|c|}
\hline \multicolumn{3}{|c|}{ Group 1} & \multicolumn{3}{|c|}{ Group 2} \\
\hline \multicolumn{3}{|c|}{ Caffeine session 1 - placebo session 2} & \multicolumn{3}{|c|}{ Placebo session 1 - caffeine session 2} \\
\hline Code & Position & Welght (kg) & Code & Position & Welght (kg) \\
\hline Player 1 & goalkeeper & 71.1 & Player 10 & goalkeeper & 80.2 \\
\hline Player 2 & fullback & 56.2 & Player 11 & fullback & 70.3 \\
\hline Player 3 & defender & 75.6 & Player 12 & fullback & 61.8 \\
\hline Player 4 & defender & 61.1 & Player 13 & defender & 69.6 \\
\hline Player 5 & midfielder & 65.4 & Player 14 & midfielder & 58.8 \\
\hline Player 6 & midfielder & 65.4 & Player 15 & midfielder & 67.4 \\
\hline Player 7 & midfielder & 65.4 & Player 16 & midfielder & 75.76 \\
\hline Player 8 & striker & 81.5 & Player 17 & striker & 68.8 \\
\hline Player 9 & striker & 80.0 & & & \\
\hline
\end{tabular}

Figure 2. Height on countermovement jumps in caffeine and placebo essays.
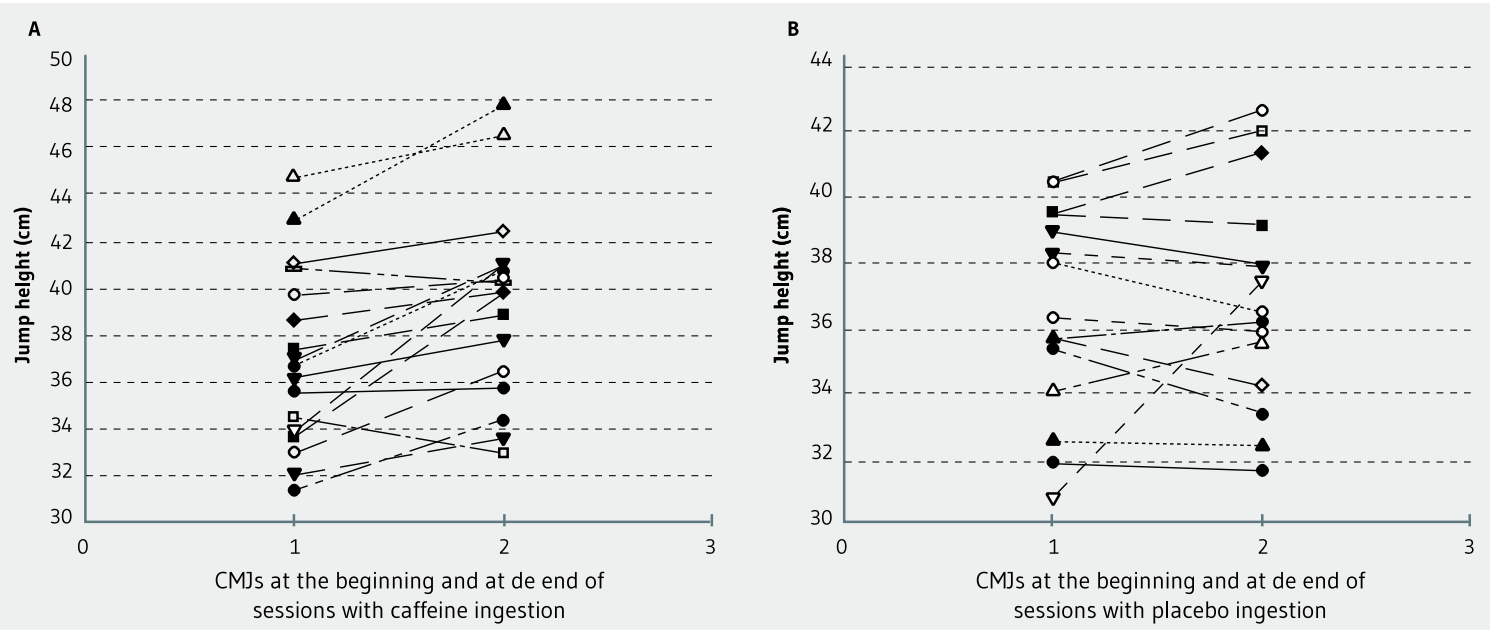

A: Height on countermovement jump pre-caffeine ingestion at the beginning of the training sessions and post-caffeine ingestion at the end of training sessions. Each data represents the individual change in jump height with caffeine administration.

B: Height on countermovement jump pre-placebo ingestion at the beginning of the training sessions and post-placebo ingestion at the end of trainning sessions. Each data represents the individual change in jump height with placebo administration. 
In comparison to placebo, caffeine increased CMJ at the end of the training as it can be observed in Figure 3. There were significant differences on jump height at the end of the sessions between caffeine and placebo ingestion (39.35 [ \pm 4.05$] \mathrm{cm}$ vs. 36.85 [ \pm 3.15$] \mathrm{cm} ; \mathrm{p}<0.05$; ES:-0.65; QA:0/1/99).

Rating of Perceived Exertion: The RPE was $13.18( \pm 3.16)$ with caffeine ingestion and $13.76( \pm 3.29)$ with placebo ingestion. There were differences between caffeine and placebo administration ( $p<0.05$; ES:0.14; QA:42/44/14).

Initial Tiredness Scale: The rate on the scale (1-10) recorded at the beginning of the sessions was $1.71( \pm 0.98)$ in caffeine group and $1.88( \pm 0.91)$ in placebo group. There were not significant differences between caffeine or placebo supplementation ( $p=0.106 ; \mathrm{ES}:-0.21 ; \mathrm{QA}: 4 / 45 / 51$ ).
Side effects from caffeine ingestion: There was a tendency showed on Table 2 to suffer more side effects in the next night hours with caffeine ingestion, but this was not significant. This questionnaire presented a 0.81 Cronbach alpha coefficient value.

\section{Discussion}

Differences on jump height were not found between players before they ingested caffeine or placebo at the beginning of the sessions indicating that both groups were in same conditions at the time of tests and intervention. Significant improvements in comparison with the initial measures at the beginning of the session were obtained with caffeine

Figure 3. Results from caffeine and placebo administration.

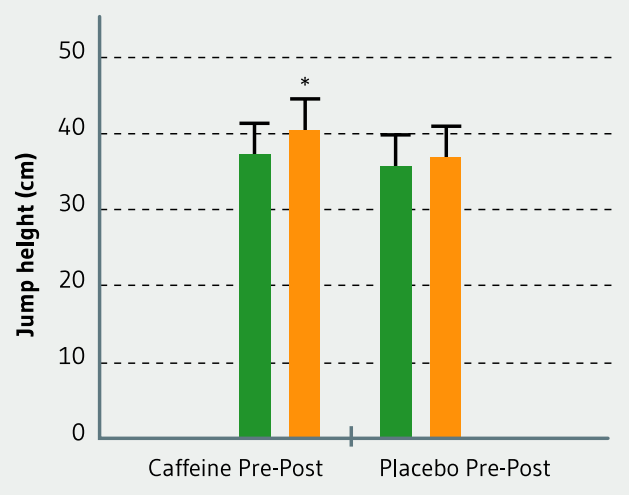

Height on countermovement jump pre and post caffeine administration and height pre and post placebo ingestion.* value was significantly different from that the placebo group at the and of training and caffeine group at the beginning $(p<0.05)$.

Table 2. Side effects derivate from caffeine and placebo ingestion.

\begin{tabular}{l|c|c|c} 
Item & Placebo (\%) & Caffeine (\%) & $p$-value \\
\hline Headache & 5.9 & 5.9 & $\mathrm{P}=1.000$ \\
Abdominal/gut discomfort & 17.6 & 5.9 & $\mathrm{P}=0.601$ \\
Muscle soreness & 0.0 & 0.0 & \\
Increased vigor/activeness & 35.3 & 11.8 & $\mathrm{P}=0.225$ \\
Tachycardia and hear palpitation & 0.0 & 0.0 & \\
Insomnia & 17.6 & 11.8 & $\mathrm{P}=1.000$ \\
Increased urine production & 11.8 & 5.9 & $\mathrm{P}=1.000$ \\
Increased anxiety & 11.8 & 5.9 & $\mathrm{P}=1.000$
\end{tabular}

Data frequencies for 17 soccer players. Fisher test. 
administration. Furthermore, significant improvements on final test jump at the end of the session between caffeine and placebo groups were observed. So, caffeine improved jump height on CM] test compared with jump height placebo group were found. In addition to previous studies $5,14,17$, we speculate that caffeine ingestion could promote a greater muscle leg production affecting to intramuscular and inter-muscular coordination during the muscle contraction improving motor unit recruitment. These beneficial effects could help to soccer players to reach higher height during jumping in actions.

A previous study ${ }^{17}$ obtained significant improvements in $\mathrm{CM}$ with caffeine ingestion $(6 \mathrm{mg} / \mathrm{kg}$ BM) in soccer players 60 minutes before exercise. They reported a greater muscle power leg generations due to an increase on maximal voluntary contraction of the vastus lateralis muscle and these ergogenic effects could be mediated through caffeine adenosine antagonist role. Caffeine supplementation could have considerable practical relevance in explosives activities during a soccer match. While in the current study similar CM] improvement have been observed with a lower dose of caffeine, although players ingested caffeine or placebo at the beginning of the training (minute 0 ) in order to observe ergogenic effects at the end of the session (minute 90). Another research ${ }^{3}$ in volleyball players administrated caffeine $(3 \mathrm{mg} / \mathrm{kg}$ BM) or placebo 60 minutes before volleyball-specific tests, including CMJ. They observed an increase on $\mathrm{CMJ}$ with caffeine in comparison with placebo. The explanation of this improvement was an increase in the production of leg muscle power giving that caffeine intake could have improved intramuscular and inter-muscular coordination during the muscle contraction and suggesting improvements in motor unit recruitment. Additionally, a similar experimental design were followed because two sessions separated by 1 week were analyzed, the design was also double-blind, placebo-controlled and randomized, a similar number of players were studied and the caffeine dose was akin. Consequently caffeine improved CM] performance in both studies.

Another study ${ }^{26}$ analyzed the effect of adding caffeine $(3.7 \mathrm{mg} / \mathrm{kg} \mathrm{BM})$ to a carbohydrate solution on a simulated soccer exercise in a rehydration and carbohydratereplacement strategy. $\mathrm{CMJ}$ were recorded before the exercise and during the simulated activity. Caffeine improved explosive leg power quantified with $\mathrm{CMJ}$ due to an improvement on voluntary activation of the quadriceps and lessened maximal contraction. In the present research carbohydrate was not administrated to the players, but alike caffeine dose was ingested by the soccer players (3.7mg/ $\mathrm{kg}$ BM versus $4 \mathrm{mg} / \mathrm{kg}$ BM). In this previous study ${ }^{26}$ caffeine group presented a higher height jumped at rest condition and during the shuttle-running trial compared with values from placebo. While in the present research, caffeine improved jump height at the end of the training in comparison with placebo. A recent study ${ }^{5}$ investigated the effectiveness of caffeine ingestion ( $3 \mathrm{mg} / \mathrm{kg} B M)$ in comparison with a placebo in physical performance in female soccer players during a simulated soccer exercise. Eighteen female soccer players ingested caffeine or placebo, they performed a CM], 7×30 sprint test and a simulated match and caffeine intake increased the CMJ height. Using an analogous caffeine intake, improvements in height jumped on $\mathrm{CMJ}$ in male soccer players were also observed.

A scale 1-10 was recorded in order to examine the initial fatigue and tiredness state and differences between the caffeine and placebo groups were not found so it could be said that players showed the same initial fatigue state. The RPE was assessed finding significant differences between caffeine and placebo, so caffeine administration could have helped to attenuate fatigue. We speculate that adenosine receptor antagonism effects from caffeine administration could result in a lower RPE allowing soccer players to work at a higher intensity perceiving less exertion than in normal conditions. A previous article ${ }^{27}$ documented these effects showing that the mechanism of action is a competitive inhibition of adenosine receptors, especially in some kinds of receptors ( $A 1$ and $A 2 A$ ).

Roberts and Cols. ${ }^{20}$ examined the effect of carbohydrate ingestion alone or with caffeine on rugby performance in male rugby forwards. Carbohydrate supplement was administered before and during the protocol while caffeine $(6 \mathrm{mg} / \mathrm{kg})$ was ingested pre-exercise. They observed that RPE was lower in the carbohydrate ingestion with caffeine than in the carbohydrate ingestion alone or in placebo ingestion so when caffeine adding rugby players reported lower perception of effort and this could be mediated by the capability of caffeine to inhibit action of adenosine on the central nervous system. In the present study, a lower RPE value where observed with caffeine compared to placebo so we speculate that caffeine could be involved in the reduction of perception effort in sport.

Killen and Cols. ${ }^{28}$ analyzed the effects of caffeine on RPE following 30 minutes constant -load cycling when they ingested caffeine or placebo, obtaining that caffeine was associated with lower RPE versus placebo due to analgesic effect of caffeine and it suggest that caffeine ingestion could promote mayor capacity to tolerate fatigue and pain resulting in an increased time to exhaustion. In the current research, it has been observed a lower RPE when players ingested caffeine than with placebo administration after the same exercise protocol so caffeine could help to tolerate 
fatigue. Green and Cols. ${ }^{29}$ evaluated effects of caffeine on number repetitions, RPE and peak heart rate (PHR) in a resistance-exercise program with repetitions performed to volitional failure when the subjects ingested $6 \mathrm{mg} / \mathrm{kg}$ BM of caffeine or a placebo. They found similar RPE with higher repetitions, therefore they could complete more repetitions without altering RPE and the authors proposed that caffeine could attenuate pain responses.

In the present research, we evaluated the side effects using the same questionnaire model of previous studies and we obtained a tendency to suffer more side effects in the following night hours derived from caffeine than placebo. However, these effects were not significantly differents so it could be suggest that caffeine do not represent an important risk to suffer sleep disturbances.

Del Coso and Cols. ${ }^{2}$ analyzed the side effects in the following hours of caffeine trials $(3 \mathrm{mg} / \mathrm{kg}$ BM) in rugby players resulting in non-significant increases on vigor/activeness and insomnia, although without affects to other side effects from caffeine administration. Other study ${ }^{21}$ examined the effects of 1 and $3 \mathrm{mg}$ of caffeine/kg BM or placebo ingestion on muscle performance in active people and they evaluated side-effects from caffeine. Caffeine on a dose of $3 \mathrm{mg} /$ $\mathrm{kg}$ of BM tended to increase the frequency of side-effects, especially "increased vigor/activeness", "tachycardia and heart palpitations", "insomnia", "increased urine production" and "abdominal/gut discomfort"21.

The present study has limitations such as the range of age, only players between 17-19 years old were examined, or the range of sex, only male soccer players were studied. These results cannot be extrapolated to all soccer players. Other important limitation would be the small soccer players sample analyzed. Moreover, they were not probabilistic selected.

\section{CONCLUSIONS}

The administration of $4 \mathrm{mg} / \mathrm{kg}$ of caffeine at the beginning of a training improved jump height on CM] compared with a measure at the beginning and compared with placebo ingestion at the end. Players showed a significant lower RPE with caffeine. There was a tendency to suffer more side effects derived from caffeine ingestion. We conclude that caffeine supplementation in a dose of $4 \mathrm{mg} / \mathrm{kg}$ of BM could improve soccer performance. However, further studies with bigger athletes sample would be necessary to refute the present results.

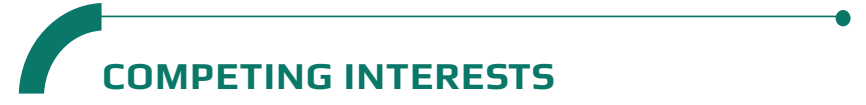

Authors state that there are no conflicts of interest in preparing the manuscript.

\section{$\longrightarrow$ REFERENCIAS}

(1) Ramírez-Montes CA, Osorio JH. Uso de la cafeína en el ejercicio físico: ventajas y riesgos. Revista de la Facultad de Medicina. 2013; 61(4): 459-68.

(2) Del Coso J, Portillo J, Muñoz G, Abián-Vicén J, Gonzalez-Millán C, Muñoz-Guerra J. Caffeine-containing energy drink improves sprint performance during an international rugby sevens competition. Amino Acids. 2013; 44(6): 1511-9.

(3) Del Coso J, Pérez-López A, Abian-Vicen J, Salinero J], Lara B, Valadés $D$. Enhancing physical performance in male volleyball players with a caffeine-containing energy drink. Int ] Sports Physiol Perform. 2014; 9(6): 1013-8.

(4) Del Coso J, Muñoz-Fernández VE, Muñoz G, Fernández-Elías VE, Ortega JF, Hamouti N, et al. Effects of a caffeine-containing energy drink on simulated soccer performance. PLOS ONE. 2012; 7(2): e31380.

(5) Lara B, Gonzalez-Millán C, Salinero J], Abian-Vicen J, Areces $F$, Barbero-Alvarez JC, et al. Caffeine-containing energy drink improves physical performance in female soccer players. Amino Acids. 2014; 46(5): 1385-92.

(6) Tucker MA, Hargreaves JM, Clarke JC, Dale DL, Blackwell G]. The effect of caffeine on maximal oxygen uptake and vertical jump performance in male basketball players. J Strength Cond Res. 2013; 27(2): 382-7.

(7) Pettersen SA, Krustrup P, Bendiksen M, Randers MB, Brito J, Bangsbo J, et al. Caffeine supplementation does not affect match activities and fatigue resistance during match play in young football players. Journal of Sports Sciences. 2014; 32(20): 1958-65.

(8) Andrade-Souza VA, Bertuzzi R, de Araujo GG, Bishop D, LimaSilva AE. Effects of isolated or combined carbohydrate and caffeine supplementation between 2 daily training sessions on soccer performance. Appl Physiol Nutr Metab. 2015; 40(5): 457-63.

(9) Astorino TA, Matera AJ, Basinger J, Evans M, Schurman T, Marquez R. Effects of red bull energy drink on repeated sprint performance in women athletes. Amino Acids. 2012; 42(5): 1803-8.

(10) Rampinini E, Coutts AJ, Castagna C, Sassi R, Impellizzeri FM. Variation in top level soccer match performance. Int J Sports Med. 2007; 28(12): 1018-24.

(11) McNaughton LR, Lovell RJ, Siegler J, Midgley AW, Moore L, Bentley DJ. The effects of caffeine ingestion on time trial cycling performance. Int J Sports Physiol Perform. 2008; 3(2): 157-63.

(12) Jordan JB, Korgaokar A, Farley RS, Coons JM, Caputo JL. Caffeine supplementation and reactive agility in elite youth soccer players. Pediatr Exerc Sci. 2014; 26(2): 168-76. 
(13) Hornery DJ, Farrow D, Mujika I, Young WB. Caffeine, carbohydrate, and cooling use during prolonged simulated tennis. Int J Sports Physiol Perform. 2007; 2(4): 423-38.

(14) Bloms LP, Fitzgerald JS, Short MW, Whitehead JR. The Effects of Caffeine on Vertical Jump Height and Execution in Collegiate Athletes. J Strength Cond Res. 2016; 30(7): 1855-61.

(15) Salinero J], Lara B, Abian-Vicen J, Gonzalez-Millán C, Areces F, Gallo-Salazar $C$, et al. The use of energy drinks in sport: perceived ergogenicity and side effects in male and female athletes. Br J Nutr. 2014; 112(9): 1494-502.

(16) Beaumont RE, Brown D, Stephenson B, Freeman C, Watson P. The effect of a low dose of caffeine on exercise performance and thermoregulation during endurance exercise in the heat. Proceedings of the Nutrition Society. 2015; 74(OCE1): E28.

(17) Foskett A, Ali A, Gant N. Caffeine enhances cognitive function and skill performance during simulated soccer activity. Int J Sport Nutr Exerc Metab. 2009; 19(4): 410-23.

(18) de Blas X, Padullés JM, Amo JL, Guerra-Balic M. Creation and Validation of Chronojump-Boscosystem: A Free Tool to Measure Vertical Jumps. Rev Int Cienc Deporte. 2012; 8(30): 334-56.

(19) Borg GA. Perceived exertion: a note on «history» and methods. Med Sci Sports. 1973; 5(2): 90-3.

(20) Roberts SP, Stokes KA, Trewartha G, Doyle J, Hogben P, Thompson D. Effects of carbohydrate and caffeine ingestion on performance during a rugby union simulation protocol. J Sports Sci. 2010; 28(8): 833-42.

(21) Del Coso J, Salinero J], González-Millán C, Abián-Vicén J, PérezGonzález B. Dose response effects of a caffeine-containing energy drink on muscle performance: a repeated measures design. J Int Soc Sports Nutr. 2012; 9(1): 21.

(22) Lara B, Ruiz-Vicente D, Areces F, Abián-Vicén J, Salinero J], Gonzalez-Millán C, et al. Acute consumption of a caffeinated energy drink enhances aspects of performance in sprint swimmers. Br ] Nutr. 2015; 114(6): 908-14.

(23) Cohen J. Statistical power analysis for the behavioral sciences. Hillsdale, N..: L. Erlbaum Associates; 1988.

(24) Hopkins WG. Spreadsheets for analysis of controlled trials with adjustment for a subject characteristic. Sportscience. 2006; 10: 46-50.

(25) Hopkins WG, Marshall SW, Batterham AM, Hanin J. Progressive statistics for studies in sports medicine and exercise science. Med Sci Sports Exerc. 2009; 41(1): 3-13.

(26) Gant N, Ali A, Foskett A. The influence of caffeine and carbohydrate coingestion on simulated soccer performance. Int J Sport Nutr Exerc Metab. 2010; 20(3): 191-7.

(27) MagkosF, Kavouras SA. Caffeine use in sports, pharmacokinetics in man, and cellular mechanisms of action. Crit Rev Food Sci Nutr. 2005; 45(7-8): 535-62.

(28) Killen LG, Green JM, O'Neal EK, McIntosh JR, Hornsby J, Coates TE. Effects of caffeine on session ratings of perceived exertion. Eur ] Appl Physiol. 2013; 113(3): 721-7.

(29) Green JM, Wickwire PJ, McLester JR, Gendle S, Hudson G, Pritchett RC, et al. Effects of caffeine on repetitions to failure and ratings of perceived exertion during resistance training. Int J Sports Physiol Perform. 2007; 2(3): 250-9. 